\title{
Ethnomedicinal Uses of Honeybee Products in Lithuania: The First Analysis of Archival Sources
}

\author{
Zivile Pranskuniene, ${ }^{1,2}$ Jurga Bernatoniene, ${ }^{1}$ Zenona Simaitiene, ${ }^{1,2}$ \\ Andrius Pranskunas, ${ }^{3}$ and Tauras Mekas ${ }^{1,2}$ \\ ${ }^{1}$ Department of Drug Technology and Social Pharmacy, Lithuanian University of Health Sciences, Kaunas, Lithuania \\ ${ }^{2}$ Museum of the History of Lithuanian Medicine and Pharmacy, Kaunas, Lithuania \\ ${ }^{3}$ Department of Intensive Care Medicine, Lithuanian University of Health Sciences, Kaunas, Lithuania
}

Correspondence should be addressed to Zivile Pranskuniene; z.pranskuniene@gmail.com

Received 17 May 2016; Revised 20 July 2016; Accepted 1 August 2016

Academic Editor: José Maurício Sforcin

Copyright (C) 2016 Zivile Pranskuniene et al. This is an open access article distributed under the Creative Commons Attribution License, which permits unrestricted use, distribution, and reproduction in any medium, provided the original work is properly cited.

\begin{abstract}
Lithuania has old ethnomedicine traditions, consisting of many recipes with herbal, animal, and mineral original ingredients. All these findings were mostly collected in Lithuanian language, often in local community's dialects, and stored only in archives. We analyzed archival sources about honeybee and its products used for medicinal purposes dated from 1886 till 1992 in different parts of Lithuania. We systematized and presented the most important information about bees and their products: indication for usage, ingredients used in the recipe, their preparation techniques, and application for therapeutic purposes. Researchers in Lithuania are now looking for new evidence based indications and preparation and standardization methods of bee products. Archival sources are a foundation for studies in Lithuania. The results can be integrated into scientifically approved folk medicine practices into today's healthcare.
\end{abstract}

\section{Introduction}

The first knowledge about Lithuanian ethnomedicine is mentioned in the chronicles of the Teutonic Knights about spells, prejudice, and traditions, since they have close connection to the folk medicine. There are documents about ethnomedicine in the 16th-17th centuries' law books of Grand Duchy of Lithuania. Cases of witches courts with witchcraft methods were mentioned. Lithuania became Christian country latest in Europe, while pagan traditions still existed after christening for a long time. These traditions had close connection with ethnomedicine $[1,2]$.

The biggest part of all Lithuanian ethnomedicine consists of the usage of traditional medicinal plants. Ethnobotanical expeditions were organized in various historical periods with the aim of preserving local knowledge about traditional uses of medicinal plants for medicinal purposes. All these findings were mostly collected in Lithuanian language, often in local community's dialects, and stored only in archives [3].
Many countries have recently engaged into studies of traditional medicine $[4,5]$ and Lithuanian researchers begin to collect, systematize, analyze, and publish ethnomedicinal studies as well [6-8]. According to ethnomedicinal global trend studies, it is important to find analysis of food on one hand and medications on the other. These categorizations offered possibility of generating information that could be ordered in a similar way in studies from different regions of the world and thus helped to make comparisons between them [9].

Ethnomedicinal preparations of animal origin make up smaller part of preparations; however, usage of preparations of animal origin is very important part of Lithuanian ethnomedicine. Bee products were important not only for nutritional purposes but also for their healing features and wide medicinal application [10-12]. Bee products can be used alone or in combination with medicinal plants, substances of animal origin, or strongly acting materials for synergistic effect, cumulative impact, or just better taste 
and administration form. In addition to bee products as food, active substances used for medicinal purposes, and inactive substances used as bases (e.g., as ointment base), they show close relationship between animal and herbal origin substances used in homemade medicine. This is a part of traditional ecological knowledge, which represents a close relationship between people and places [13].

To find parallels within ethnopharmaceutical (including bee products) research, we look to countries with similar history, nature, and ethnomedical traditions. For this reason, in most cases, Lithuanian researches compare their studies with studies from Poland. Unfortunately, such works are limited [3, 14]. Information about medicinal plants and animals traditionally used for therapeutic purposes is mainly deficient, since archive material is not systematized and mostly presented in small ethnographic papers published in native languages $[15,16]$. This problem, also with scarce information on bee products, highlights Polish researches [3, 6, 17]. Also researches organize studies with migrant communities and investigate situation; then people moved to urbanized areas and despite the availability of primary healthcare they often bring with them the traditional medical knowledge and actively use it. Systematic archival material can facilitate comparative analysis in such kind of investigations $[18,19]$.

Purpose of our study was to systematize unpublished archival material which concerns the use of bee products from ethnographic expeditions in Lithuania. This is the first analysis of unpublished material not only for scientific audience but also in local literature too. This study is important for complementing Lithuanian ethnomedicine data base and also can be useful for researches from other countries to find parallels between studies. Recently, researchers in Lithuania are looking for new evidence based indications and preparation and standardization methods of bee products. Certainly, ideas come from Lithuanian ethnomedicine archives and nowadays public opinion research.

\section{Methods}

We analyzed archival sources, that is, the material from ethnographic expeditions, dated from 1886 till 1992 in different parts of Lithuania. Among plenty of ethnobotanical information, it also includes preparations from animal origin. We systematized and presented the most important information about bee and its products: indication to use, ingredients used in the recipe, their preparation techniques, and application for therapeutic purposes.

\section{Results and Discussion}

In Lithuanian ethnomedicine, we can find recipes with bee products, and even whole bee, for the treatment of various ailments. We registered 65 reports regarding bee products used for medicinal purposes (Table 1). Only 39\% of all usage was for internal use and the most popular preparation methods were ointments and compresses (22\% and 19\% from all reports, resp.). The most popular indications were abscesses, wounds, and contagious diseases, such as measles and smallpox. These explain bee products as antimicrobic substances. Honey is the only one of our registered bee products used internally (despite some cases of whole bee, honeycomb, and propolis) and it is the most popular from registered products.

Scientifically inexplicable usage of bee products is explained by archaic traditions and observation of the natural world and an understanding based on the theory of signatures. Only in this way can we explain bee usage as an antidote from viper's bite and fumigation with honeycombs for the same indication.

We registered cases when bee products are used alone or in combination with plants, animals, or additional material: 11 plant species and 8 animal products, such as powders of dried toad, swine bile, goose, chicken fats, dog's and pig's lard, cow's milk, and chicken's eggs. As additional products, cream, butter, vodka, and soap material were used in household.

3.1. Bee, Apes. Until the 18 th century bee was described as diuretic and hair loss inhibitive remedy in pharmaceutical literature [20]. It was used in homeopathy for the treatment of allergy and swellings. In Lithuanian folk medicine, according to archival sources, bee's poison was used as antidote to viper's poison. "For epilepsy healing, the drinking the water with boiled dead bees (dead after the winter time) were used" (Table 1). Numerous practices used whole bee for medicinal purposes: "bee glue was used to put on ulcers and boils"; "bee glue was used to put on purulent gatherings for faster removing of purulence" [archival source: LLTI, 1081, pp. 55].

3.2. Honey, Mel. In Old Egypt, in the Ebers Papyrus, honey was the only active ingredient in an ointment described for application to the surgical wound of circumcision [5]. Honey could provide some kind of protection from various kinds of bacteria. It was used on the infected wounds to encourage the healing processes. The ancient Egyptians were not the only people who used honey as medicine. The Chinese, Indians, Ancient Greeks, Romans, and Arabs used honey in combination with other herbs or on its own to treat wounds and various other diseases [21].

Honey is one of the oldest and most famous materials of animal origin. There was a big amount of external drug forms containing honey in Lithuania. According to archival sources, honey (for external usage, alone or in combination) was usually used to treat wounds, abscess (Table 1), and even pain in the body: "from the pain in the body I have mix honey, butter, fat and rue leaves and used a teaspoon daily. After one week my health improved and pain disappeared" [archival source: LLTI. B4575.733/117]. In the Polish traditional medicine, honey has been used for respiratory diseases, gastrointestinal disorders, and dermatological problems. According to our study, the most popular indication for internal use of honey was respiratory disorders and no reports for gastrointestinal disorders were mentioned. But today's study with Polish settlements in Argentina demonstrates that most popular indication is also respiratory disorders [9]. Honey is the most popular material of bee products used up to now according to ethnomedicine studies in other countries and researches mainly focus on these studies $[22,23]$. 


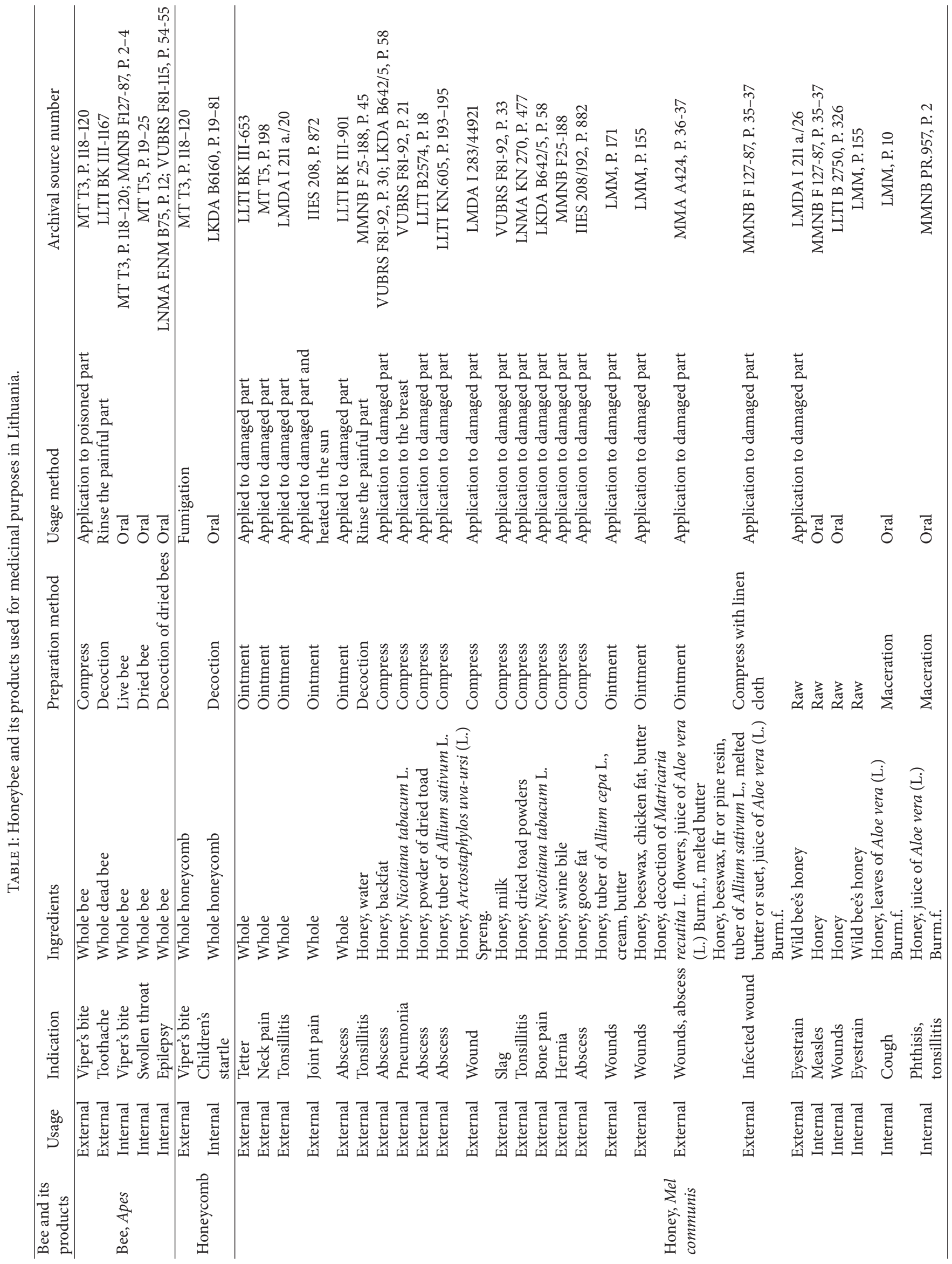




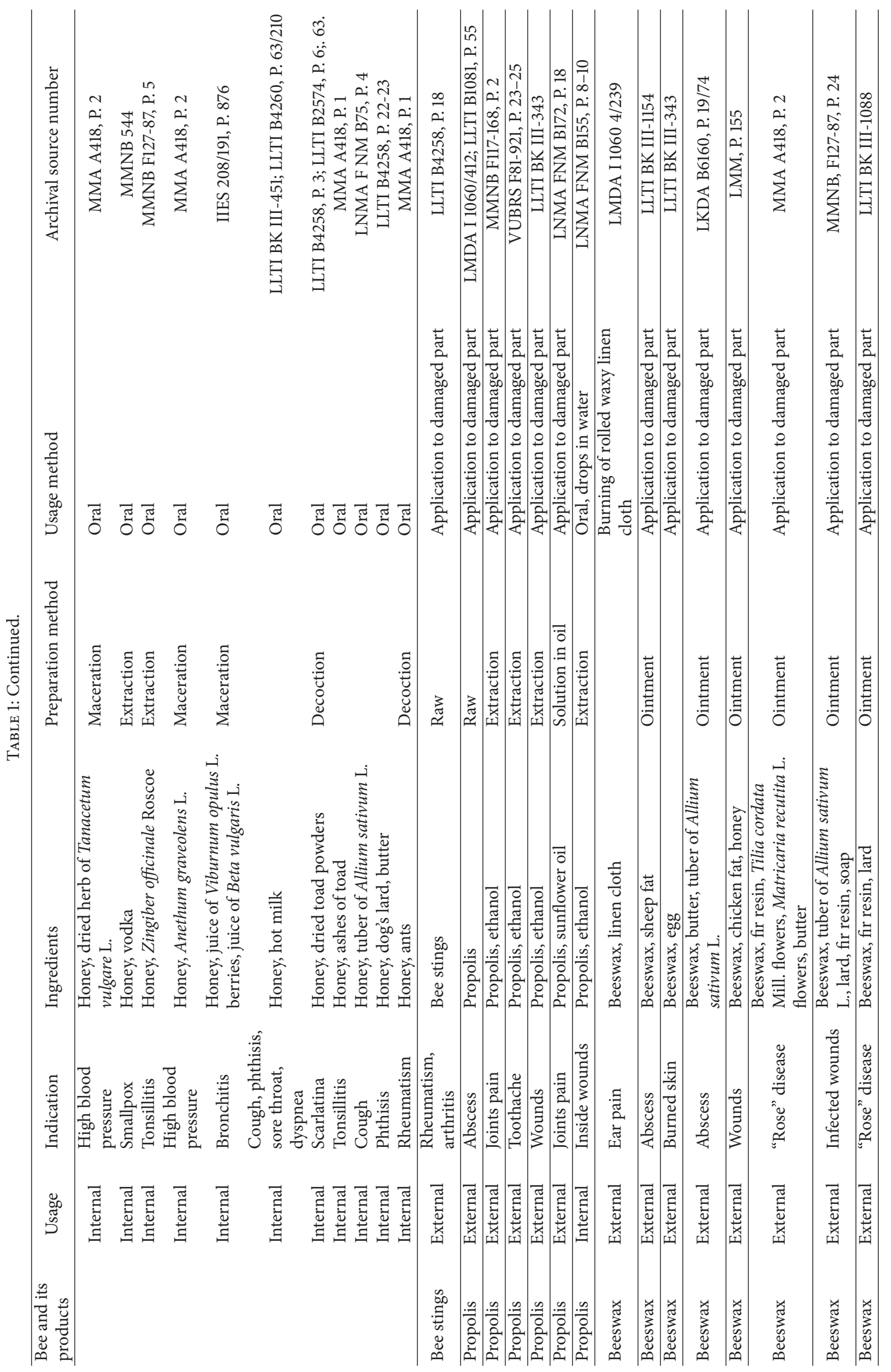


Nowadays, scientific studies indicate that honey contains major amounts of carbohydrates, lipids, amino acids, proteins, vitamins, and minerals that have important roles in wound healing with minimum trauma during redressing. Laboratory studies and clinical trials have shown that honey promotes autolytic debridement, stimulates growth of wound tissues, and stimulates anti-inflammatory activities, thus accelerating the wound healing processes [24]. Internally, it was used for various respiratory tract disorders. When ingested, honey also promotes healing and shows antibacterial action by decreasing prostaglandin levels, elevating nitric oxide levels, and exerting prebiotic effects. The use of honey leads to improved wound healing in acute cases, pain relief in burned patients, and decreased inflammatory response in such patients $[25,26]$.

According to the scientific studies, honey has antiseptic, curative properties and acts as effective broad-spectrum antibacterial agent [26]. The antimicrobial qualities of honey explain the external and internal uses of honey in Lithuania.

3.3. Bee Stings, Venenum Apium. Bee stings are some kind of injections and were used for treating rheumatism (Table 1). According to archival material, "bee stings were used for arthritis treatment"; "bee stings were used for rheumatizm healing" [archival source: LLTI, 2574, pp. 13].

Other researches highlight the therapeutic application of bee venom which has been used in traditional medicine to treat diseases, such as arthritis and rheumatism, and to relieve pain [27] and clinical trials also reveal bee sting therapy for rheumatoid arthritis and get positive results [28]; also bee venom acupuncture for rheumatoid arthritis is one of the opportunities for the treatment [29].

After viper's bite, according to archival sources, "just let bee to sting or put bee into bread and give it to eat" [archival source: LLTI, 3503, pp. 84].

3.4. Propolis, Propolim. Dioskorid described propolis as sliver extractor and also for fumigation from chronic cough. This is a pharmacopoeial remedy from the 16th century to the 18th century [20]. In Lithuania, it was used as oily or alcohol extract. According to our archival sources, propolis was used to treat wounds and joint pain. It is prepared with ethanol or with oily solution (Table 1).

Despite recent advances in wound care products, traditional therapies based on natural origin compounds, such as plant extracts, honey, and propolis, are interesting alternatives. These therapies offer new possibilities for the treatment of skin diseases and allow overcoming some limitations such as the increase in the bacterial resistance. Current trends move to the development of innovative wound care treatments, combining the use of traditional healing agents (such as propolis and honey) and modern products, such as dressing films and hydrogel sheets containing honey [30]. Also studies show that propolis is a potent antioxidant and a free radical scavenger [31, 32].

Lithuanian scientists have been focusing on investigation of propolis qualities and propolis preparations development. They identified that propolis therapeutic application does

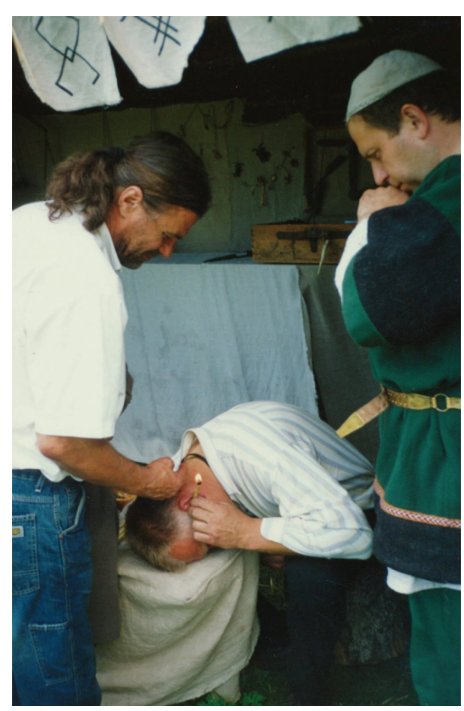

FIGURE 1: Ear pain relief by burning of rolled waxy linen cloth (demonstration).

not induce germ resistance and does not destroy useful microflora [33]; study explains our findings using propolis for wound care not only with ethanolic solution, but also in a form of oily solution (Table 1). Nowadays, bee products, particularly honey and propolis and its preparations (tablets, suppositories, ointments, mouth sprays, and others), are available in most of the Lithuanian community pharmacies usually positioned as dietary supplements [34].

3.5. Beeswax and Honeycomb, Cera Alba, Flava, and Favum Mellis. Fumigation with Ibio shaped piece of wax was described in Ebers Papyrus. It was used when the uterus went down. Dioscorides described the pills of beeswax as a remedy that stops diarrhea [20].

Fumigation with wild honeycombs is very old method of cure, used to cure viper's bite (Table 1). Also, "if children got a fright, the honeycomb tea was used for treating" [LLTI number 6160.81].

White beeswax and yellow beeswax were an important part of ointments and plasters. Other researches investigating ethnopharmaceutical formulations in other countries also find beeswax as material for formulation of ointments [35]. In a study done by Kacániová et al. [36], it was found that the extracts of beeswax were effective against pathogenic bacteria, so this material can be used as antimicrobial agent too. It explains our findings for beeswax used in ointments form to treat wounds, abscesses, and burned skin.

In Lithuanian ethnomedicine, ear pain relief by burning of rolled waxy linen cloth is very interesting (Figure 1). The same method is known in Chinese medicine but instead of linen silk is used. Also beeswax still is used as a component in cosmetic preparations (ointments, lip pencils, etc.), for its acting as protective film on the skin and mucous membranes [37]. 


\section{Conclusions}

Treatment techniques with bee and its products in Lithuanian ethnomedicine have survived since the times when qualified medical assistance was hardly accessible. It is a unique fact that in modern times of developed medical assistance even young people in Lithuania actively use traditional bee products and combine them with modern medicine. These unpublished archival materials demonstrated that bee products not only were a part of plant or animal origin homemade medicines but also were among main ingredients in the recipes for the treatment and prevention of common diseases in the studied area. Archival sources are a foundation for studies in Lithuania.

The results can be integrated into scientifically approved folk medicine practices into today's healthcare.

\section{Competing Interests}

The authors declare that there are no competing interests regarding the publication of this paper.

\section{References}

[1] J. Surkus, Lietuviu Liaudies Medicinos Tyrinejimu Apzvalga, Medicina, Vilnius, Lithuania, 1973.

[2] J. Skliutauskas, "Apie liaudies medicina," Medicina, vol. 6, pp. 414-418, 1931.

[3] Ł. Łuczaj and W. M. Szymański, "Wild vascular plants gathered for consumption in the Polish countryside: a review," Journal of Ethnobiology and Ethnomedicine, vol. 3, article 17, 2007.

[4] M. R. González-Tejero, M. Casares-Porcel, C. P. Sánchez-Rojas et al., "Medicinal plants in the Mediterranean area: synthesis of the results of the project Rubia," Journal of Ethnopharmacology, vol. 116, no. 2, pp. 341-357, 2008.

[5] A. Pieroni and C. Gray, "Herbal and food folk medicines of the Russlanddeutschen living in Künzelsau/Taläcker, SouthWestern Germany," Phytotherapy Research, vol. 22, no. 7, pp. 889-901, 2008.

[6] Z. Petkeviciute, N. Savickiene, A. Savickas et al., "Urban ethnobotany study in Samogitia region, Lithuania," Journal of Medicinal Plants Research, vol. 4, no. 1, pp. 064-071, 2010.

[7] Z. Petkeviciute and T. A. Mekas, "The prospects of ethnopharmaceutical-botanical research in Lithuania," Theory and Practice in Medicine, vol. 17, no. 1, pp. 77-82, 2011.

[8] T. Mekas and Z. Petkeviciute, "Parallels between ethnopharmaceutic research in wilno in 1927 and at wornie in 2007," Analecta: Studia i Materiały z Dziejów Nauki, vol. 19, no. 1-2, 36-37, pp. 8391, 2010.

[9] F. Zamudio, M. Kujawska, and N. I. Hilgert, "Honey as medicinal and food resource. Comparison between Polish and Multiethnic Settlements of the Atlantic Forest, Misiones, Argentina," The Open Complementary Medicine Journal, vol. 2, no. 2, pp. 58-73, 2010.

[10] J. Skliutauskas, Del Lietuviu Liaudies Medicinos Tyrinejimo Mokslines ir Praktines Reiksmes, 1958.

[11] A. Macius, "Kaip seniau zmones gydesi ir kokius vaistus vartojo," Farmacijos Zinios, vol. 5, pp. 28-32, 1939.

[12] A. Vileisis and N. Parazinskaite, Lietuviu Liaudies Gydomosios Priemones, 1958.
[13] I. Nesheim, S. S. Dhillion, and K. A. Stølen, "What happens to traditional knowledge and use of natural resources when people migrate?" Human Ecology, vol. 34, no. 1, pp. 99-131, 2006.

[14] J. Muszynski, "Wilenskie ziola ludowie," Wiadomoszczi Farmaceutycznie Wasszawa, vol. 4, pp. 21-22, 1927.

[15] A. Urbiene, Liaudies medicina, Vilnius, 1985.

[16] E. Simkunaite, "Lietuviu liaudies vaistingieji augalai," 1948.

[17] Ł. Łuczaj, P. Köhler, E. Piroznikow, M. Graniszewska, A. Pieroni, and T. Gervasi, "Wild edible plants of Belarus: from Rostafiński's questionnaire of 1883 to the present," Journal of Ethnobiology and Ethnomedicine, vol. 9, article 21, 2013.

[18] A. Pieroni, Q.-Z. Sheikh, W. Ali, and B. Torry, "Traditional medicines used by Pakistani migrants from Mirpur living in Bradford, Northern England," Complementary Therapies in Medicine, vol. 16, no. 2, pp. 81-86, 2008.

[19] A. Pieroni, H. Muenz, M. Akbulut, K. H. C. Başer, and C. Durmuşkahya, "Traditional phytotherapy and trans-cultural pharmacy among Turkish migrants living in Cologne, Germany," Journal of Ethnopharmacology, vol. 102, no. 1, pp. 69-88, 2005.

[20] A. Tschirch, Allgemeine Pharmakognosie, 2nd edition, 1932.

[21] L. Boukraa, Honey in Traditional and Modern Medicine, CRC \& Taylor \& Francis, 2010.

[22] A. M. Ajao, Y. U. Oladimeji, S. K. Babatunde, and A. Obembe, "A study of the use of honey and ethno-biological components in Nigerian trado-medical practices," British Journal of Applied Science \& Technology, vol. 4, no. 19, pp. 2796-2807, 2014.

[23] A. Reyes-González, A. Camou-Guerrero, O. Reyes-Salas, A. Argueta, and A. Casas, "Diversity, local knowledge and use of stingless bees (Apidae: Meliponini) in the municipality of Nocupétaro, Michoacan, Mexico," Journal of Ethnobiology and Ethnomedicine, vol. 10, article 47, 2014.

[24] A. Oryan, E. Alemzadeh, and A. Moshiri, "Biological properties and therapeutic activities of honey in wound healing: a narrative review and meta-analysis," Journal of Tissue Viability, vol. 25, no. 2, pp. 98-118, 2016.

[25] N. S. Al-Waili, K. Salom, G. Butler, and A. A. Al Ghamdi, "Honey and microbial infections: a review supporting the use of honey for microbial control," Journal of Medicinal Food, vol. 14, no. 10, pp. 1079-1096, 2011.

[26] R. Yaghoobi, A. Kazerouni, and O. kazerouni, "Evidence for clinical use of honey in wound healing as an anti-bacterial, anti-inflammatory anti-oxidant and anti-viral agent: a review," Jundishapur Journal of Natural Pharmaceutical Products, vol. 8, no. 3, pp. 100-104, 2013.

[27] S. Roy, S. Saha, and P. Pal, "Insect natural products as potential source for alternative medicines-a review," Word Scientific News, vol. 19, pp. 80-94, 2015.

[28] X. D. Liu, J. L. Zhang, H. G. Zheng, F. Y. Liu, and Y. Ci, "Clinical randomized study of bee-sting therapy for rheumatoid arthritis," Zhen Ci Yan Jiu, vol. 33, no. 3, pp. 197-200, 2008.

[29] J. A. Lee, M. J. Son, J. Choi, J. H. Jun, J.-I. Kim, and M. S. Lee, "Bee venom acupuncture for rheumatoid arthritis: a systematic review of randomised clinical trials," BMJ Open, vol. 4, no. 11, Article ID e006140, 2014.

[30] R. F. Pereira and P. J. Bártolo, "Traditional therapies for skin wound healing," Advances in Wound Care, vol. 5, no. 5, pp. 208$229,2016$.

[31] O. Baltas and S. Kolayli, "Inhibition properties of propolis extracts to some clinically important enzymes," Journal of Enzyme Inhibition and Medicinal Chemistry, vol. 7, pp. 1-4, 2016. 
[32] A. C. De Groot, "Propolis: a review of properties, applications, chemical composition, contact allergy, and other adverse effects," Dermatitis, vol. 24, no. 6, pp. 263-282, 2013.

[33] K. Ramanauskiene, A. M. Inkeniene, A. Savickas, R. Masteikova, and V. Brusokas, "Analysis of the antimicrobial activity of propolis and lysozyme in semisolid emulsion systems," Acta Poloniae Pharmaceutica-Drug Research, vol. 66, no. 6, pp. 681688, 2009.

[34] S. Trumbeckaite, J. Dauksiene, J. Bernatoniene, and V. Janulis, "Knowledge, attitudes, and usage of apitherapy for disease prevention and treatment among undergraduate pharmacy students in Lithuania," Evidence-Based Complementary and Alternative Medicine, vol. 2015, Article ID 172502, 9 pages, 2015.

[35] R. Tahvilian, S. Shahriari, A. Faramarzi, and A. Komasi, "Ethnopharmaceutical formulations in Kurdish ethno-medicine," Iranian Journal of Pharmaceutical Research, vol. 13, no. 3, pp. 10291040, 2014.

[36] M. Kacániová, N. Vuković, R. Chlebo et al., "The antimicrobial activity of honey, bee pollen loads and beeswax from Slovakia," Archives of Biological Sciences, vol. 64, no. 3, pp. 927-934, 2012.

[37] L. Budai, I. Antal, and I. Klebovich, "Natural oils and waxes: studies on stick bases," Journal of Cosmetic Science, vol. 63, no. 2, pp. 93-101, 2012. 


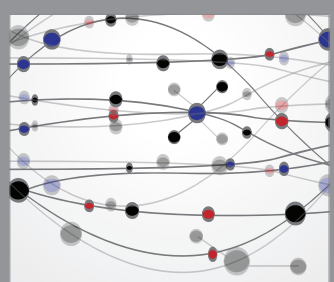

The Scientific World Journal
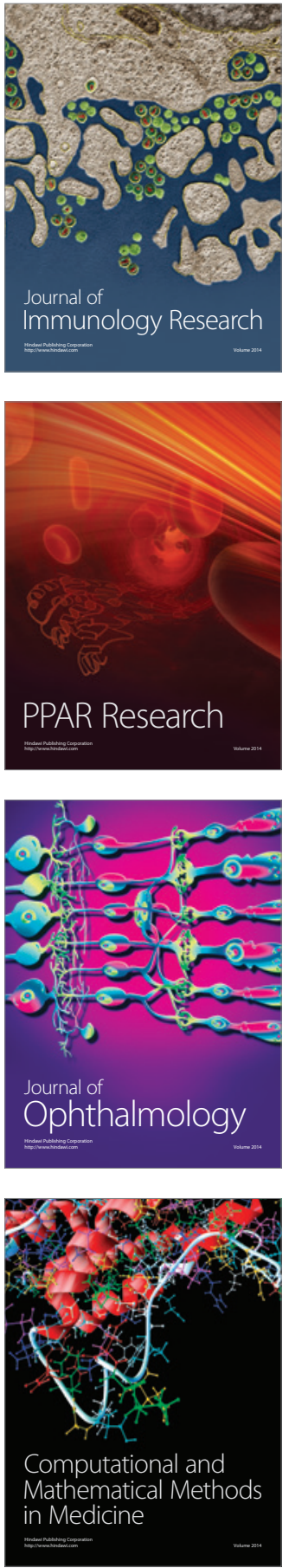

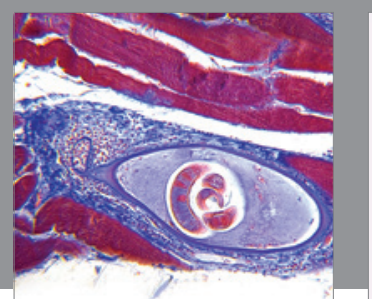

Gastroenterology Research and Practice

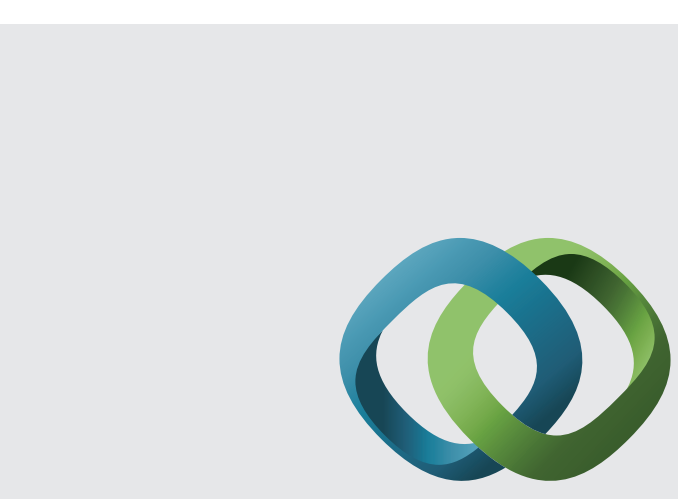

\section{Hindawi}

Submit your manuscripts at

http://www.hindawi.com
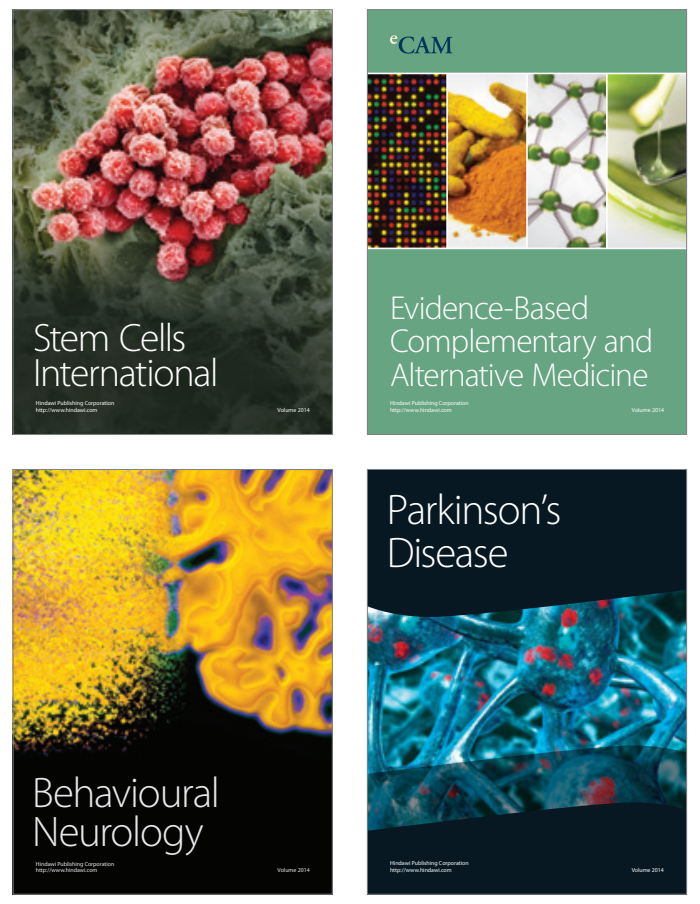
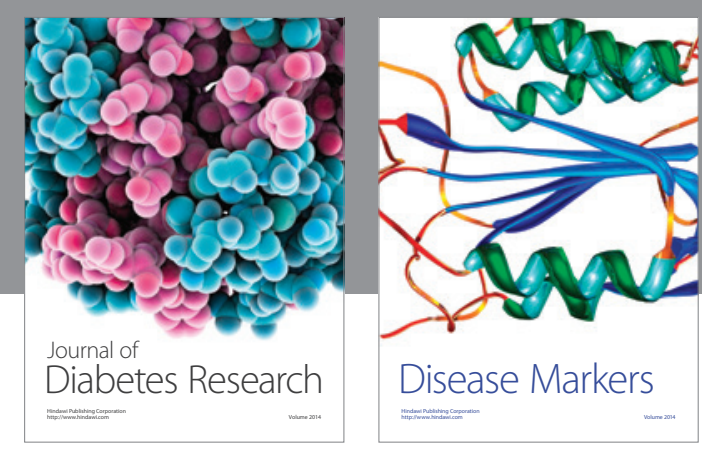

Disease Markers
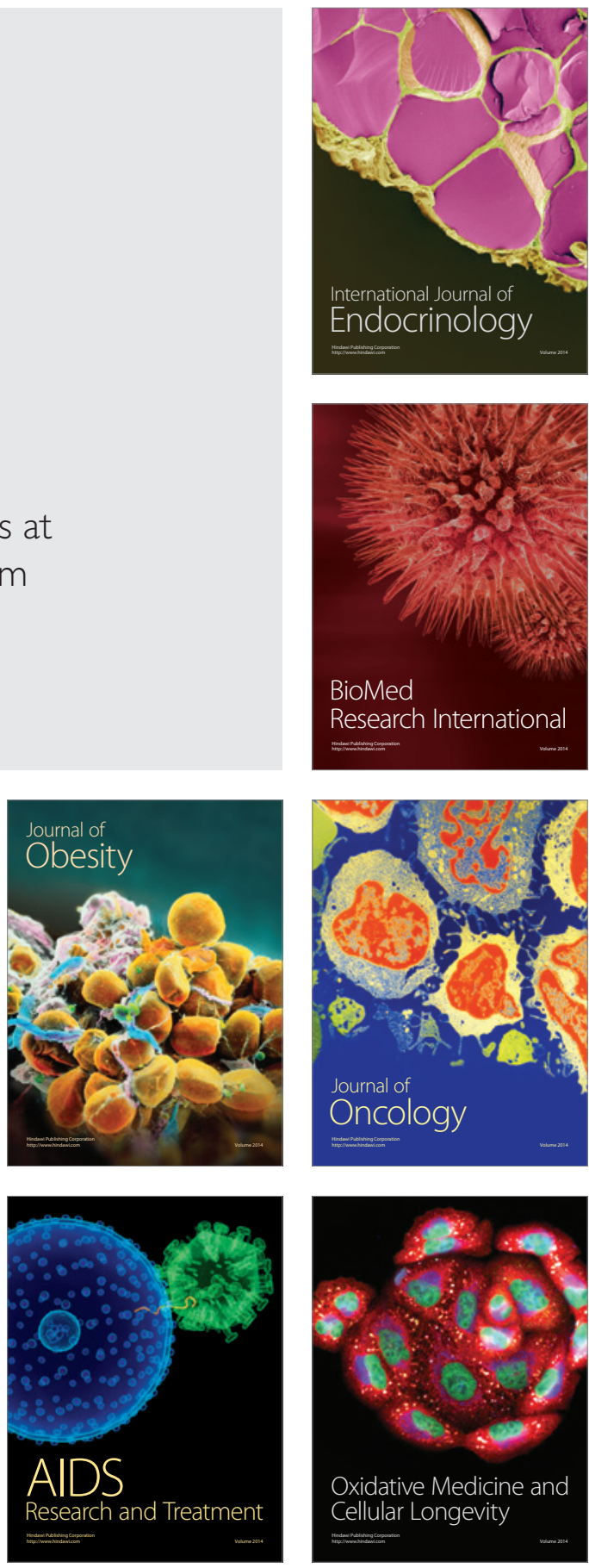